\title{
Water in Morocco, Retrospective at the Political, Regulatory and Institutional Levels
}

\author{
Machrafi Othman1*, Sguigaa Ayoub², Sabir Mohamed2, Mohamed Qarro², Naimi Mustapha1, \\ Chikhaoui Mohamed', Attou Ayoub1 \\ ${ }^{1}$ Institut Agronomique et Vétérinaire Hassan 2, Rabat, Maroc \\ ${ }^{2}$ Ecole Nationale Forestière d'ingénieurs, Salé, Maroc \\ Emai: othman.machrafi1995@gmail.com, ayoubsguigaa@gmail.com, miloudsaadia@hotmail.com,mohamedq53@gmail.com, \\ mnaimi2005@gmail.com,mchikhaoui@gmail.com, attouayoub@gmail.com
}

How to cite this paper: Othman, $\mathrm{M}$. Ayoub, S., Mohamed, S., Qarro, M., Mustapha, N., Mohamed, C. and Ayoub, A. (2022) Water in Morocco, Retrospective at the Political, Regulatory and Institutional Levels. Open Journal of Modern Hydrology, 12, 11-31.

https://doi.org/10.4236/ojmh.2022.122002

Received: January 31, 2022

Accepted: March 1, 2022

Published: March 4, 2022

Copyright (c) 2022 by author(s) and Scientific Research Publishing Inc. This work is licensed under the Creative Commons Attribution International License (CC BY 4.0).

http://creativecommons.org/licenses/by/4.0/

\begin{abstract}
Water, a primary source of life, in Morocco, is recognized as a major problem due to its scarcity on the one hand, the multiplication and interdependence of uses, the overlap of responsibilities between public and private actors, and the superposition of regulatory texts on the other hand. It is in this sense that a retrospective analysis of water management in Morocco has been made to highlight the reconfigurations and successive legislative and institutional reforms that the water sector has undergone, the constraints and shortcomings that this sector has experienced and the solutions undertaken to remedy them. Its developmental orientation, managed since independence by the Ministry of Public Works, was strongly correlated with water even after the reforms of 2002 and 2007. The institutional reform led to the creation of the Hydraulic Basin Agencies (HBAs) as a response to the severe drought problems that characterized the early 1980s. The modern twist could respond to the operational difficulties of Integrated Water Resources Management IWRM by focusing the missions of these agencies as regality of the State, while the political orientation towards large-scale irrigated agriculture also led to their focus on meeting the supply side. This generally explains the creation of institutions that are weak enough, in terms of bureaucratic power, not to interfere with the general direction of the country and not to threaten the prerogatives of other powerful administrations such as agriculture and the interior. For this reason, efforts could also have been made to institute coordination mechanisms between the different sectors to put the sectoral plans and master plans in order to strengthen the coordination and regulation role of the Hydraulic Basin Agencies (HBAs). The country is also subject to exogenous harmonization of water policies because of donors who make their loans and project financing conditional on the establishment of a water re-
\end{abstract}


sources management organization.

Keywords

Water Management in Morocco, IWRM, HBA, Basin Agency, Policy, Retrospective Analysis

\section{Introduction}

The importance of water as a life support and regulating factor of a country's development is universally recognized. Moreover, the international forums on water have highlighted the strategic global nature of the water issue [1]. Henceforth, water scarcity and conflicts over water have become the key words of a new problematic [2]. Extremely varied uses, whether for industry, fishing, irrigation or drinking water production, all are subject to new vulnerabilities. Climate change caused by human activity and greenhouse gas emissions is having a profound impact on water resources.

Today, the world is facing a water crisis that is seriously affecting living and production conditions, jeopardizing efforts to fight poverty and promote sustainable development, especially in developing countries. In many cases, water resources are poorly managed, resulting in inefficient use and deepening the crisis.

Like the countries of the southern Mediterranean region, Morocco is currently experiencing water stress, mainly due to strong demographic growth, the relative improvement in the living standards of its inhabitants and economic policies that have given priority to export agriculture and tourism. These observations have led to reflection on measures to accompany the changes and meet this global challenge.

In this context of crisis and increased rivalry between users of water, the process of managing the resource becomes complex. This complexity is illustrated in the relationship between the water resource as an infrastructural resource, its uses, its users, its territoriality, and its management methods, which constitutes a solid straitjacket in front of sustainable management of the resource. Indeed, the current inadequate and inconsistent management of the water resource would not be valid for a constrained future including climate change and socio-economic development.

The general objective of this work is to analyse the current and past management of water resources, on the political, institutional and regulatory levels, to identify the innovations necessary for sustainable management and adaptation to climate change. It is in this spirit that the projects targeting water and soil conservation in order to maintain sustainable agricultural development in the context imposed by climate change in Morocco have been interested in retrospective and current analyses of water resources management strategies and techniques to identify the various adaptation strategies and techniques that will 
be incorporated into the prospective scenarios in terms of adaptive water resources management.

Hence, the specific objective assigned to this work is the realization of a retrospective and current analysis of water management in Morocco from a political, regulatory and institutional point of view at the national scale.

\section{Methodological Approach}

\subsection{Analysis of the Political Aspect}

Since independence, the water sector has been part of different mid-term configurations due to changes in the country's political orientations.

The study of this aspect was based essentially on a review of the available literature on this subject [3] [4] [5] [6] and on interviews and semi-structured interviews with researchers involved in the debate on water management at the national level. These interviews and interviews focus mainly on the origins and consequences of the dynamics of the reconfigurations and reforms that the water sector has undergone since independence to the present day.

In another part, the focus will be on how the IWRM and basin agency models have been appropriated in Morocco. The way public policy decisions are implemented is as crucial to the process of change as the decisions themselves [7] and there is often a resilience of public policies prior to the change, or institutional reconfigurations [8].

\subsection{Analysis of the Regulatory Aspect}

The success of appropriate water legislation depends on the existence of effective administrative mechanisms to implement it [9]. The analysis of the legal and institutional system in Morocco integrates religious tradition and customs alongside the so-called modern texts that date from the period of the French Protectorate [10].

The objective of this analysis is to identify the regulatory means available to the water management system and to understand how they fit together in good water governance.

To do this, we will first analyse the traditional legal status of water in Morocco, namely the legal status of water in Muslim law (Malekite). Secondly, a reading of the new water law (36-15) is proposed, questioning its capacity to respond to the challenges of integrated management and good governance on the basis of the difficulties of the previous law (10-95).

\subsection{Analysis of the Institutional Aspect}

The large number of administrative units working in the water sector and the multiplicity of laws and systems in this area create complexity in the management of water resources.

The analysis of this institutional aspect, consists in drawing up a diagnosis of the current situation of the administrative organization of water at the national, 
regional and local levels, revealing the challenges and constraints of coordination in the field of water to come out with a new reading of the institutional scheme of the water sector.

\section{Results and Discussion}

\subsection{Political Aspect}

After the period of the Protectorate (1912-1956), Morocco kept the reservoir dams and the orientation of the production system towards export crops (citrus, early market gardening) [11].

Since that time, the water sector has often been placed under the supervision of the Ministry of Public Works or the Ministry of Equipment. This Ministry had as its administrative body in charge of water the Administration of Hydraulics (AH) which evolved into the General Directorate of Hydraulics (GDH) in the 1990s. The main tasks of this structure are: on the one hand, the study and realization of waterworks and, on the other hand, the planning and execution of water infrastructure development plans.

This positioning is justified by the existence of a political confusion inherited from the protectorate between the irrigation policy and that of the dams. The effect of this confusion is to place water among the issues of agricultural policies and the convergence of Moroccan policies towards a developmental vision that focuses essentially on the construction of hydro-agricultural works. Water management during this period was shared simultaneously between the Ministry of Public Works, which was responsible for the construction and management of hydro-agricultural works and equipment, and the Ministry of Agriculture and Forestry, which was in charge of small and medium-sized waterworks.

The National Office of Irrigation (NOI) was created in 1960, born from the observation of the fragmented nature of the State's operators involved in irrigation, having the largest development budget in the country, it had an autonomy of decision that largely freed it from the government councils [4]. The NOI was a real turning point in Moroccan policy on agricultural hydraulics [12]. Most of the participants were engineers, but there were also speakers from the human and social sciences [13].

In addition, the NOI took responsibility for agrarian reform, which at the time aroused considerable interest among the political parties, and highlighted the inequality of access to land. From a development point of view, the irrigation system chosen was gravity-fed. This choice was justified by the availability of manpower and traditional know-how, in addition to financial reasons, since the gravity-fed irrigation system was less expensive in terms of investment. In this orientation, it is necessary to note the absence of interest and ambition to safeguard and save water as a natural resource.

In 1967, the policy of dams was born to highlight the government's orientation towards the development of irrigated agriculture and to break with previous policies [4]. 
It should also be noted that in 1978, public investment earmarked for irrigation accounted for a significant portion of gross public investment. In 1978, the 1978-1980 Three-Year Plan allocated 30.7 percent of rural and hydro-agricultural equipment [4].

Although this policy was launched in the 1960s, it was not implemented until 1974 , when it increased from 10,000 ha per year to 25,000 ha per year [12].

The post-independence period is characterized by the implementation of agricultural plans and programs: the operation ploughing and the campaign of the sectors of modernization of the peasantry (SMP) whose aim was to increase cereal production through the introduction of improved agricultural methods, including the use of fertilizers and varieties of selected seeds; and to reform the mechanisms of production while avoiding land reform [6].

Both programs were overly idealistic, poorly planned, and negligently executed. The peasants, who were supposed to be the beneficiaries of these projects, did not fully understand their goals, were suspicious of the government's intentions, rebelled against the authoritarian manner in which these programs were imposed, and resisted their implementation. The rural elite also opposed both programs, seeing them as a threat to the status quo. Finally, after a few years, these projects were abandoned by the government and represent resounding failures [6].

In 1992, a phase of "institutional reorganization and redefinition of politics" [5] was launched in response to King Hassan II's desire to overcome the political difficulties that had handicapped the kingdom for a long time [14]. At first, the environment sector was institutionalized as a State Secretariat (SS) under the Ministry of the Interior in 1992. It maintained this status of State Secretariat until 1995. This year was characterized by the creation of the Ministry of Environment in the 23 rd government. Simultaneously, with the creation of the Ministry, a National Council of the Environment and Regional Councils of the Environment. It is also created a Council of the environment at the level of each wilaya or failing that at the level of each province (Official Bulletin No. 4294 of $15 / 02 / 1995)$ in charge of ensuring the integration of environmental concerns in the process of economic and social development in order to achieve the objectives of sustainable development (Official Bulletin No. 4294 of 15/02/1995).

In 2002, the environment was added to water in the same ministry: the Ministry of Energy, Mines, Water and Environment. Followed by the promulgation of the law 10-95 which was the cornerstone for the birth of the water sector. Water is no longer considered only as a factor of production but it is taken in its entirety as a sector in its own right. The promulgation of the law 10-95 on water marked a turning point in the water policy in Morocco, especially through the establishment of the framework of a real Integrated Water Resources Management (IWRM) oriented much more towards "the management of the demand" [15]. Thus, the introduction of the concepts of participatory, concerted and decentralized water management [16]. 
The climate of globalization prompted the 10-95 law on water to create the Hydraulic Basin Agencies (HBA) responsible for the regulation and management of water resources. The HBAs have kept the same administrative structure as the regional hydraulic directorates of the RHD whose headquarters became that of the Basin Agencies [17]. Thus, the RHD agents will continue to carry out their tasks but within a basin agency, a new institution, seeking its interest and role in the existing political-administrative system.

In 2002, the water sector was separated from the Ministry of Public Works and Equipment. As a result, the supervision of the water sector became the responsibility of the Ministry of Land Management, Water and the Environment, and water was directly administered by the State Secretariat (SS) in charge of water. According to the World Bank (2004): "The integration of the three sectors of Land Use Planning, Water and Environment in the same ministerial department can be considered a positive measure for the water sector in that it allows the socio-economic and environmental dimensions of water policy to be reinforced".

In 2007, the water sector was merged with the environment, energy and mining sectors into a single ministry (Ministry of Energy, Mines, Water and Environment). Integrating theoretically divergent sectors into the same ministry is a common concept with uncertain consequences. In some cases, the interest given to different sectors within the ministry is uneven, causing the repression of environmental issues [18].

The case in point is when the merger between potentially conflicting sectors allows the creation of a regulatory pole in the field of environmental protection and natural resources in general and water in particular. So instead of unresolved conflicts between ministries, the resolution of these conflicts internally is forced, with the purpose of making decisions that have the character of integration.

In 2017, the water sector was placed under the supervision of the Ministry of Equipment, Transport, Logistics and Water. This historical review of the path taken by the sector imposes several observations. The change in configuration from "Water/Public Works or Equipment", "Water/Territorial Planning/Environment", "Water/Mining/Energy/Environment" and finally "Water/Equipment" illustrates a great difficulty in the political system for the adequate positioning of the water sector in the political-administrative ecosystem and which will be at the same time adapted to its complex nature of interrelation with the other sectors. Since in Morocco, in addition to the administrative hierarchy within each ministry, there is a hierarchy between the different ministries. Depending on their seniority, political and economic weight, the ministries are not of the same order of magnitude. Given the historical importance of the water sector, it can be used to reinforce the power of a particular sector/ministry/ministry, which is partly what leads to the understanding of the water dynamics within the ministerial configurations. 
While theoretically, administrative reorganizations have multiple purposes, including the optimization of administrative organization, new policy orientations, political power-sharing, or state reform... [19].

Political-administrative reforms or changes are determined by several factors, namely the configuration of the administrations, the history, the interconnections of the components of the political-administrative system [20]. The nature of these reforms requires a change in administrative culture and individual and collective professional identity [21]. Since the administrative structures subject to the reforms are not paper beings, but institutions, that is to say supra-individual realities charged with history, depositories of traditions, knowledge, know-how and routines and in that, places of socialization of their members, conveying principles, values and beliefs that are attached to them [21].

In the case of the water sector in Morocco, managed since independence by the Ministry of Public Works, the planning orientation was strongly correlated with water even after the reforms of 2002 and 2007. This can be partially explained by the retention of public works administration staff in the new ministry configurations.

In addition to the successive changes in the ministerial configuration related to the water sector, other reforms have taken place, notably that concerning water legislation. A historical retrospective allows us to understand the basis of these changes and their content.

\subsubsection{IWRM (Integrated Water Resources Management) Ownership in Morocco}

The application of the variables of the "RBO" analysis proposed by Bloomquist et al. [22] revealed problems related to the creation of RBOs. These institutions, generically called RBOs (River Basin Organisations), are generally responsible for the coordination and integration of different sectoral policies and/or the combined management of surface and groundwater, upstream and downstream, quantity and quality [23]. The need to establish basin organizations is sometimes associated with international cooperation actions or development bank loans invoking sustainability, participation and good governance [24] [25].

In Morocco, the institutional reform that led to the creation of the Basin Agencies was a response to the serious drought problems that characterized the early 1980s. This type of problem obviously conditioned the type of agency set up. Contrary to France, for which the problem at the origin of the creation of financial agencies was rather qualitative [26] [27] [28] (generalized pollution of watercourses), the nature of the problem that Morocco had to face was rather quantitative (as for Spain), relating to the satisfaction of needs to meet the growing needs of irrigation essentially.

This undoubtedly conditioned the nature of the missions assigned to these institutions, particularly in terms of the management of hydraulic works and supply management. The Moroccan political orientation towards large-scale irrigated agriculture has also reinforced the focus of the Basin Agencies on the sa- 
tisfaction of supply, and more generally explains the creation of institutions that are weak enough, from the point of view of bureaucratic power, not to impede the general orientation of the country and not to threaten the prerogatives of other powerful administrations such as agriculture and the interior.

\subsubsection{Initiative "Top-Down" or "Bottom-Up"}

The involvement (or not) of the reform by the actors within the basin or the administration is directly influenced by an important variable, the "top-down" or "bottom-up" initiative. The institutionalization of collective action is present when the initiative is "bottom-up" as in the case of Germany or the Netherlands. On the other hand, the Spanish hydrographic confederations are the product of the central State and play a centralizing role to the detriment of the traditional "top-down" local authorities. In Morocco, the reform of the water law and the emergence of basin agencies were initiated by King Hassan II at the first meeting of the High Council for Water and Climate in 1989, in response to the severe drought that the country experienced in the late 1980s. This disaster (the drought) was the occasion to set up the Basin Agencies for rather political considerations and stabilization of the country, thus confirming the idea that "the state of emergency tends rather to strengthen the power of the Nation-State" [29]. The creation of agencies was done first in the Oum Er Rbia in 1998 presented as a pilot basin, and then be generalized in two stages (2000 and 2009) to the entire country. It is therefore an entirely top-down initiative.

\subsubsection{Influence of International Organizations; A Transfer of Models for Good Water Governance}

The country has been the recipient of various public policy models in the water sector (IWRM, Basin Agency, Demand Management, Groundwater Contract...) which have benefited from the financial and technical support of international organizations (the World Bank and the FAO). The bilateral cooperation, in particular the GIZ with its "IWRM Convention" and its support to the groundwater contracts, has also played a determining role in the choice and the implementation of these models.

In both cases of model transfer, these international transfer contractors relied on model experiences or pilot projects that were supposed to provide proof of the success of the transferred model. The Oum er Rbia pilot agency and the Souss aquifer contract can indeed be seen as carefully constructed images of the test [of the performance of these models], which have become banners of new modes of governance, although the actual evidence of their success is very thin [30].

Morocco has thus undergone an exogenous harmonization [31] of water policies that partially meets the requirements of international and bilateral agencies. As in many developing countries, donors make their loans and project financing conditional on the establishment of water resource management bodies. In India, for example, the World Bank has financed water sector restructuring 
projects in various states, with the obligation to set up "water management authorities or commissions" [32].

Finally, this influence of international organizations also reflected a general tendency on their part to promote "good practices" from which they expect successful replication [33]. These good practices reflect their adherence to certain concepts that are largely ideological (decentralization, the user-pays and polluter-pays principles, faith in economic tools and in particular pricing, integrated basin management, drip irrigation, etc.). This faith also reflects a hope, shared by the government, that technical, managerial or institutional "fixes" can provide socially acceptable solutions.

\subsubsection{Structure and Functions of the Basin Agencies}

Legally, the Moroccan Basin Agency is a public establishment of an administrative nature with legal personality, just like the French and Spanish basin organizations. Nevertheless, the difference lies in the different tasks for which they are responsible. The missions of the Basin Agencies, instituted by law 10-95 and confirmed by law 36-15, as well as those of the Spanish "confederaciones", are diverse and extensive, unlike the French financial agencies for which they are more limited (Table 1).

Indeed, the French Water Agency does not exercise regal missions (as for Spain and Morocco), which are ensured by the deconcentrated services of the ministries concerned. Its missions are limited to the planning of water resources and the financial management of abstraction and pollution charges, which it carries out in consultation with the stakeholders through the basin committee, and under the control of the State. The operators and the territorial public establishments deal with the construction of dams and the management of the facilities [34]. The French Water Agencies are neither public establishments of the State collecting taxes nor facilitators of "water markets". They are public establishments at the service of their users, brought together to protect the environment in the most efficient way possible by agreeing, as in their original model [34].

On the other hand, in Spain, the hydrographic confederations, attached to the logic of large-scale works inherited from the Franco era [35], have missions focused on the development of water resources, and are in charge of the design, execution and operation of hydraulic works, resource planning and water policing. These tasks are carried out in consultation with the users, who are organized in various specialized committees. The Spanish confederations thus play a dual role, mixing regal tasks and tasks more related to integrated resource management (Table 2).

For Spain, the political choice to develop a "productivist mode of agricultural production based on intensive capitalist agriculture partly intended for export" [35], coupled with sustained urbanization and a booming tourist sector, inevitably has repercussions on water resources. As a result, despite the reform of the Spanish water law (in 1985), the country is still clearly focused on the implementation of hydraulic infrastructures. 
Table 1. Comparison between the agency model in Morocco, Spain and France (Part 1).

\begin{tabular}{cccc}
\hline & \multicolumn{3}{c}{ Model } \\
\cline { 2 - 4 } & Spanish & French & Moroccan \\
\hline $\begin{array}{c}\text { Main problem } \\
\text { generating the } \\
\text { creation }\end{array}$ & $\begin{array}{c}\text { Mobilizing water } \\
\text { to meet growing } \\
\text { demand }\end{array}$ & $\begin{array}{c}\text { Coping with } \\
\text { widespread river } \\
\text { pollution }\end{array}$ & $\begin{array}{c}\text { Mobilization of } \\
\text { water to meet the } \\
\text { growing demand }\end{array}$ \\
Source of funding & $\begin{array}{c}\text { Public institution } \\
\text { Own funds and state } \\
\text { subsidies }\end{array}$ & Public institution & Public institution \\
& Own funds & $\begin{array}{c}\text { Own funds and State } \\
\text { subsidies }\end{array}$ \\
\hline
\end{tabular}

Table 2. Comparison between the agency model in Morocco, Spain and France (Part 2).

\begin{tabular}{cccc}
\hline Missions and tasks of the RBO & \multicolumn{3}{c}{ Model } \\
\cline { 2 - 4 } Administration of the PWD & Spanish & French & Moroccan \\
Development of ER databases & $\mathrm{X}$ & $\mathrm{X}$ \\
Water policing & $\mathrm{X}$ & $\mathrm{X}$ \\
Resource planning & $\mathrm{X}$ & $\mathrm{X}$ & $\mathrm{X}$ \\
Resource management (allocation) & $\mathrm{X}$ & $\mathrm{X}$ & $\mathrm{X}$ \\
Study and realization of hydraulic works & $\mathrm{X}$ & & \\
Operation and maintenance of waterworks & $\mathrm{X}$ & $\mathrm{X}$ \\
Design and construction of flood protection works & $\mathrm{X}$ & $\mathrm{X}$ \\
Technical assistance to users & $\mathrm{X}$ & $\mathrm{X}$ & $\mathrm{X}$ \\
Financial assistance to users & & $\mathrm{X}$ & $\mathrm{X}$ \\
\hline
\end{tabular}

The Moroccan Basin Agency is a hybrid institution, mixing the attributions of the French and Spanish models. It is thus in charge of the State's regal missions and the management of major works, directly inherited from the former hydraulic directorates, and of new missions related to the integrated management of water resources, in particular the management of permits and pollution and abstraction fees. It is also in charge of project management for flood control. Only the construction of water resources mobilization works is the responsibility of the State.

The basin agency in Morocco has for regal missions of the State (administration of the Public Water Domain PWD, management of shortage and floods, water police...), a mission of planning of water resources (MPIDWR "Master Plans of Integrated Development of Water Resources", local plans of water management at the local level (sub-basins), management, control and quantitative and qualitative follow-up of water resources...), technical assistance missions to the actors and management of fees, a mission of management and maintenance of the main hydraulic works, as well as being in charge of project management and infrastructures for flood control. 


\subsection{Regulatory and Institutional Aspects}

The success of appropriate water legislation depends on the existence of effective administrative mechanisms for its implementation [9].

The analysis of the legal regime of water in Morocco, allows raising that the Moroccan legal and institutional device integrates the religious tradition and the customs beside the texts known as modern which date from the period of the French Protectorate [10]. The two origins are often contradictory and the question raised by this observation is to know if this anchoring of traditional norms and modern provisions constitutes a handicap or a wealth. On the other hand, the political orientation that Morocco had encourages the use of water for purposes mainly dedicated to irrigation by considering it as a production factor to increase productivity. This vision gives water a status very close to that of land. The key issue here is to identify the regulatory means available to the water management system and to understand the way in which they are articulated in coherent policies.

\subsubsection{Regulatory Issues of Water Management in Morocco}

According to Muslim law, whatever land the water is on, it is the property of the entire Muslim community and exceptionally it becomes private property. The right of ownership over water is neither absolute nor exclusive. Its application is based primarily on geographical reasons, driven by the scarcity of the water resource, as well as by social and religious ties [10]. The Malekite rite is the most favorable to the idea of private appropriation of water. It divides water into two categories: those that are susceptible to private appropriation and those that are not. However, all customs distinguish between water that originates in a private land and is without dispute the exclusive property of the landowner and that which originates in a land that is not privately appropriated, which highlights the communal character of this water, and requires particular modes of distribution [9].

In Morocco, local traditions and customs are more important than the rules of Muslim law. For this reason, water in Morocco has remained a collective good. But it is privately owned by a community and not for the use of all, nor is it a property of the state. According to El Menouar [9], the water share on these collective waters is inalienable. The collectivity takes back the share when the land is not cultivated. The exception is when the Djemaa (commune) loses interest in the use of the water right after its temporary allocation, in which case the water right can be rented, sold for its holder [9].

The protectorate in Morocco intervened to form the new legal corpus that would establish the rules for the rational use of water, which was largely destined for agricultural purposes.

The most important step in the evolution of the legal corpus of water in Morocco is the adoption of the Dahir No. 1-95-154 of August 16, 1995 concerning the promulgation of the law 10-95 on water. Indeed, the hydraulic basin is the most suitable geographical unit for the resolution of water resource management 
problems, as well as for achieving effective regional solidarity between users and strengthening the existing institutional framework. To this end, the Water Law creates basin agencies whose mission is to assess, plan and manage water resources at the level of hydraulic basins. Thus, thanks to the flexibility in management and decision making that the basin agencies can have, all water users in the same basin can benefit from the financial support and technical assistance necessary for their operations relating to the use of the public hydraulic domain.

This law will indeed be an effective means of combating water pollution, it being understood that achieving this objective also requires additional legislative work in the field of coastal management and the regulation of chemical products used in productive economic activities. It will make it possible to establish new rules of water use more appropriate to the economic and social conditions of modern Morocco and will lay the foundations for effective water management in the future to meet the challenges expected for the security of the country's supply.

However, the law 10-95 remains inapplicable since its application texts are not yet in force. And this delay is due to the complexity of the treated matter and to the multiplicity of the actors in the field of the water resources.

The analysis of the different provisions of the water law, shows that some waters escape from the public hydraulic domain, and are susceptible to private appropriation, in particular, rainwater, immediately collected in artificial basins or containers for the benefit of the owners on whose land this water has fallen, without forgetting the waters and watercourses on which property rights are legally acquired. These rights could only have been acquired prior to the promulgation of modern water legislation on the basis of the legal orders that existed previously. The answer, therefore, to this question lies in the hands of the judge, the doctrine and to some extent the administration, which proceeds to the recognition of these rights [9].

Law $36-15$ on water has been elaborated in order to consolidate the achievements of law 10-95, to fill the legal vacuum and to accompany the general orientations of the national strategy as well as the national water plan.

Law 36-15 can be seen as a partial translation of the recommendations of the $\mathrm{EU}$ and the World Bank. It incorporated aspects not covered by the previous water law, namely non-conventional water sources, groundwater contracts, and irrigation water saving. It also streamlined the permitting procedures and added.

\subsubsection{The Institutional Issues of Water Management in Morocco}

The administration of water resources in Morocco is sectoral and is characterized by the multiplicity of stakeholders, both at the national and regional or local level. This leads to pressures and overlapping responsibilities, causing obstacles to the implementation of an integrated, coherent and decentralized management. The diagnosis of the current situation of the administrative organization of water at the national, regional and local levels has revealed the complexity of water management, which is reflected in the institutional scheme of water. 
The institutional organization around water, as presented in official documents, classifies the different stakeholders according to their missions

- Consultative bodies;

- Coordination bodies;

- Sectoral planning and decision-making bodies;

- Public establishments and water users.

From Figure 1 it can be seen that this classification does not show the levels of intervention for the different institutions operating in the water sector. It also fails to take into account the regulatory role that the Ministry of Water should play as a sectoral administration, like agriculture or health. And finally, the positioning of the basin agency alongside public establishments (users of the resource) does not suit the agency's effective role.

\section{The consultative bodies}

The law on water institutes the High Council for Water and Climate (HCWC) which, in fact, has been created since 1981. It is in charge of "formulating the general orientations of the national policy on water and climate" (Law 10-95). This Council is the translation of the will of coordination and intersectoral dialogue which characterizes the reform of the law and which, here, takes place at the central level. The decree implementing law 10-95 (decree no. 2-96-158 of 20 November 1996) also instituted a permanent committee of the Council, which meets as often as necessary-at least twice a year-to prepare the meetings of the HCWC, to monitor the implementation of its recommendations, and to examine any matter related to water and climate policy that is submitted to it.

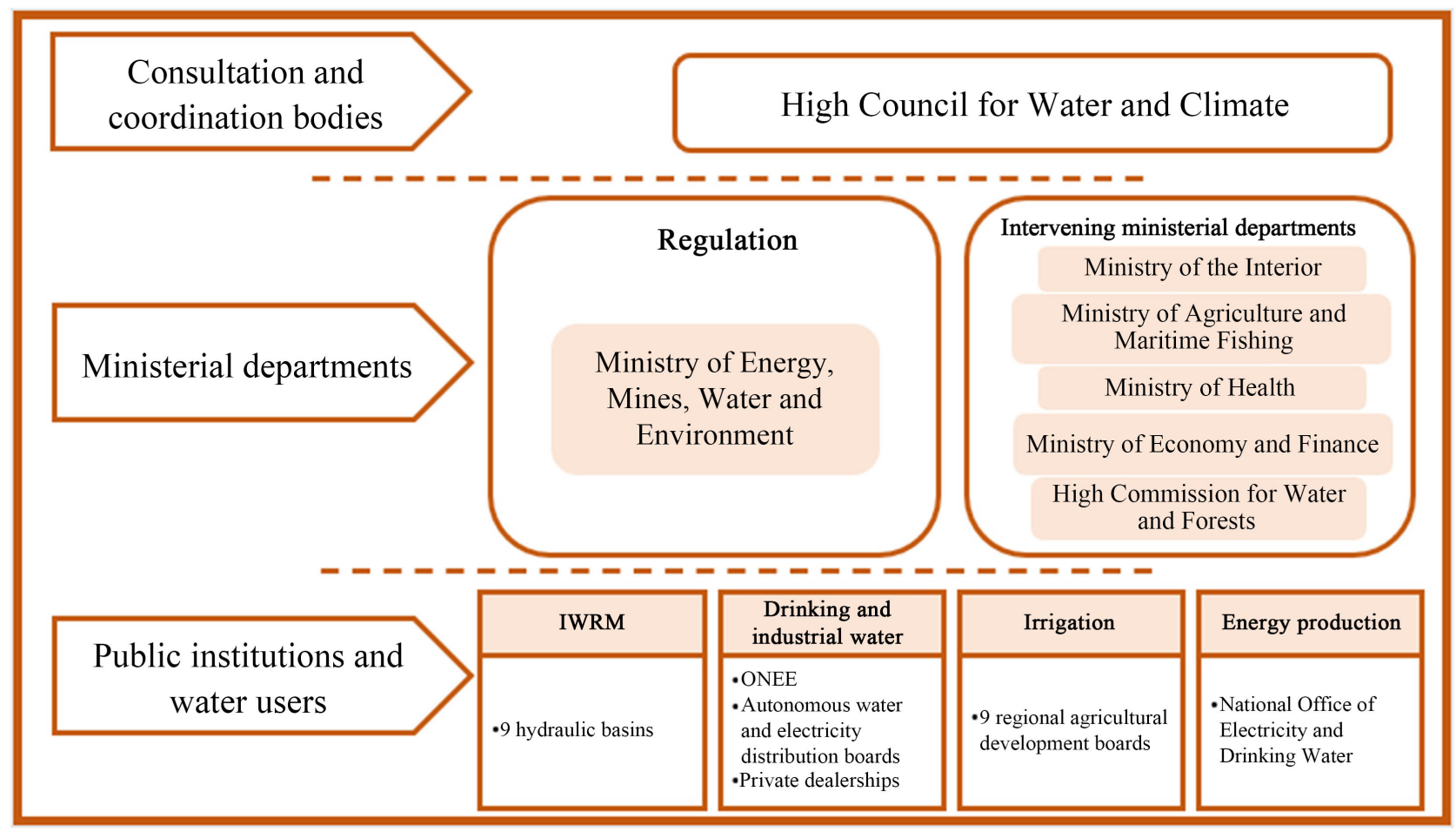

Figure 1. Official institutional scheme of the water sector (Department of Water, 2013 in HCWC report, 2014). 
The National Environment Council was established in 1995 (Decree No. 2-93-1011), as well as decentralized Councils at the level of each Wilaya or province. The mission of this Council is "to work for the protection and improvement of the environment in order to preserve the ecological balance of the natural environment (water, soil, air, fauna, flora and landscape); to prevent, combat and reduce pollution and nuisances of all kinds as well as to improve the living environment and conditions. It also strives to ensure the integration of environmental concerns in the process of economic and social development in order to achieve the objectives of sustainable development" (Decree No. 2-93-1011, Article 2). In practice, this Council prepares an annual inventory of environmental problems in the kingdom.

Water and the environment are strongly linked, especially in Morocco, even at the administrative level. The separation of the Water Council from the Environment Council raises the issue that the coexistence of two Councils creates a need for coordination between two institutions, a slowness in the exchange of information caused by administrative protocol, and a risk of overlap (actions/studies) between the two entities. Merging the two councils could streamline exchanges, harmonize and better target actions between them.

The establishment of prefectural and provincial commissions is intended to consolidate decentralization and enable local authorities to play a more important role in water resource management. These powers are limited to simple recommendations, guidelines or advice to the communes and the population. The Prefectural and Provincial Water Commissions do not have the financial means to undertake these actions, and are only active during extreme events (drought, floods, etc.).

By limiting the number of members of the PWC to 14 (Decree No. 2-97-488 of February 4, 1998 on the composition and operation of the PWCs), Law 10-95 on water penalizes the other stakeholders in the water sector (departments in charge of mines, the environment or industry, associations, etc.).

\section{The coordination bodies}

The interministerial water commission was established by a circular from the Prime Minister following the 9th session of the Higher Council for Water and Climate held in Agadir.

It brings together representatives of all the ministerial departments concerned by the issue of water and its secretariat is provided by the Secretary of State for Water. The inter-ministerial commission is supposed to be a platform for discussion to ensure the convergence of the various sectoral programs related to water, thus avoiding overlaps, oppositions or divergences.

However, this commission only carried out its mission until 2005. It then experienced a long period of inactivity that lasted nearly 10 years, which deemed it necessary to reactivate it. The Interministerial Water Commission thus comes to respond to real constraints of lack, or even absence of convergence between the various existing sectoral strategies (Speech by the Minister in charge of water, 
Ms. Charafat Afilal, on February 2, 2015 in Rabat, during the first meeting of the Interministerial Water Commission since its institutionalization by decree on November 25, 2014).

\section{Sectoral planning and decision-making bodies}

Five ministries are directly involved in water management: the Ministry of Energy, Mines, Water and Environment (MEMWE) through its Secretariat of State for Water (SSW), the Ministry of the Interior (MI), the Ministry of Agriculture and Maritime Fishing (MAMF), the Ministry of Finance (MF) and the Ministry of Health (MH).

Different responsibilities, sometimes not very well defined, are assigned to the directorates of each ministry. For example, the Ministry of Agriculture and Maritime Fisheries maintains prerogatives in agricultural water management (in irrigated areas) and collects fees for the Basin Agency. Also, responsibilities for drinking water supply and sanitation are shared between the MEMWE, which is responsible for managing the public hydraulic domain and dams and supervising the NOWE (National office of water and electricity), which is responsible for producing $80 \%$ of the country's drinking water, and the MI. The latter is responsible for supervising the autonomous water boards and concessions through its Directorate of Regies and Concessioned Services (DRCS) and for assisting municipalities in planning water and sanitation infrastructures through the Water and Sanitation Department (WSD). The Ministry of Finance, through its Water, Energy and Mining Division, monitors public companies (NOWE, Regies, etc.) and follows the fiscal aspects of public operators and concession contracts. Other responsibilities are assigned to the Ministry of Health $(\mathrm{MH})$ which is responsible, through its Directorate of Epidemiology and Disease Control (DEDC), for the implementation of the regulatory framework for drinking water and table water. The High Commission for Water and Forests and the Fight against Desertification is also involved in the water sector, mainly through watershed management planning.

\section{Public institutions and water users}

NOWE was created in 2012 by Law No. 40-09, following the merger of two national offices, the National Office of Drinking Water (NODW) and the National Office of Electricity (NOE).

The law specifies that NOWE "ensures the missions and activities assigned to NOE and NODW" which are cited in the articles that led to the creation of these two offices. Thus, NOWE, for its water branch is mainly responsible for planning the supply of water distribution, the study, implementation and management of conveyance and distribution of drinking water and thirdly the technical assistance, control in monitoring the quality of drinking water.

Thus, NOWE is a public establishment of an industrial and commercial nature placed under the supervision of the Ministry of Energy, Mines, Water and the Environment. It is therefore supposed to operate in parallel and in coordination with the orientations of the MPIDWRs in each basin and the national water 
plan NPW at the national level. However, NOWE has a certain autonomy due to its nature as the managing office of a highly sensitive sector, drinking water sanitation, which gives it an important place and priority over other sectors in meeting needs in the event of shortages. The Office also has a great deal of room for maneuver due to its expert status and its seniority in the Moroccan political and administrative landscape (NODW was created in 1973).

Placed under the supervision of the Minister of Agriculture, the regional offices for agricultural development (ROAD) are public establishments responsible for the agricultural development of the irrigated areas created under the major hydropower program. The ROADs assume the functions of operation (irrigation programming, agricultural hydraulic experimentation, control of the proper execution of the irrigation program, monitoring of the evolution of soils under irrigation and drainage), maintenance and upkeep of the preventive network as well as the collection of irrigation water fees and supervision.

Since 1966, nine ROADs have been created in the Doukkalas, Tadla, Ouarzazate, Gharb, Haouz, Moulouya, Tafilalet, Loukkos and Souss regions, with the objective of entrusting a single project manager, at the regional level, with the development of integrated agricultural enhancement actions. Thus, the ROADs manage the waters of the PWD-by virtue of the powers delegated to them by the Secretary of State for Water-and also operate the public irrigation and sanitation facilities located in their areas of action.

Under the 2002 communal charter, the public drinking water supply service is the responsibility of the communes. However, the actual organization of the management of the public drinking water supply and distribution service (and sanitation) takes many forms:

- Direct management: in this case, the municipality itself manages the service by operating it and providing the staff and various resources.

- In autonomous management: these are public communal establishments, with a commercial and industrial character and endowed with legal personality and financial autonomy, created by deliberation of the Communal Council to ensure the management of a public service within the perimeter of the commune.

- In delegated management, as defined by the law No. 54-05, that is to say a contract by which "a legal person of public law, called 'delegator', delegates for a limited time the management of a public service of economic nature for which it is responsible, to a legal person of public or private law, called 'delegatee' by recognizing him the right to take the remuneration from the beneficiaries or to make profits on the said management". As a result, two types of delegate share the management of concession contracts: NOWE (formerly NODW) and private operators.

- Agreements with associations (civil society) for the management of standpipes, especially in small rural centers.

Law 10/95 in its article 20 stipulates that the Hydraulic Basin Agency (HBA) is 
"a public establishment, endowed with legal personality and financial autonomy". It assigns to it a significant number of regal missions, of project management (planning, management, technical studies, infrastructure construction...) and of allocation of fees:

- To draw up the integrated water resources development master plan MPIDWR for its area of action; and to ensure its application;

- To issue the authorizations and concessions for the use of the public water domain provided for in the MPIDWR of its area of action; and to keep a register of these recognized authorizations and water rights;

- To provide all financial aid and services, especially technical assistance, to public or private persons who request it, either to prevent the pollution of water resources, or for the purpose of development or use of the public water domain;

- To carry out all piezometric and gauging measurements as well as hydrological, hydrogeological, planning and water management studies, both quantitative and qualitative; to carry out all quality measurements and to apply the provisions of this law and the laws in force relating to the protection of water resources and the restoration of their quality, in collaboration with the governmental authority in charge of the environment;

- To propose and implement appropriate measures, including regulatory measures, to ensure water supply in case of water shortage (...) or to prevent flooding;

- To manage and control the use of mobilized water resources;

- To carry out the infrastructures necessary for the prevention and the fight against floods.

Their mission is also to facilitate the various actions of common interest to the basin, by allocating and collecting fees (polluter-pays system) intended to finance the improvement of the resource and the reduction of pollution, and to provide financial aid and technical assistance to any individual or legal entity investing in the development of techniques for mobilizing, developing or protecting water resources.

Thus, when examining the attributions of the HBAs, we note that planning at the national level and the realization of works and developments necessary for the mobilization of water resources (dams, boreholes, wells, etc.) do not appear there. These responsibilities fall within the remit of the central services of the MEMWE, which draw up the national water plan NWP and carry out the mobilization works that they make available to the HBAs.

Similarly, there is a risk of overlap between the responsibilities of the agencies and those of the MEMWE and NOWE in terms of pollution prevention and control. These can be avoided through coordination between the various stakeholders.

Finally, Article 23 of the Water Law 10-95 lists the financial resources of the HBAs, which are subsidies, loans, donations, advances and, more particularly, fees collected from water users and the PWD-which represent the main re- 
source-without defining the agency's operating and investment expenses, the terms of repayment of advances, loans and borrowings, and any other expenses related to its activity. Similarly, the water law makes no provision for the tax treatment to be applied to BHAs.

In summary, a textual reading of the water law allows for a new institutional scheme different from the one presented in the official documents.

\section{Conclusions}

The law on water stipulates the principle of balanced management of surface and groundwater resources in order to satisfy and reconcile the various uses of water without damaging the natural balance. The complexity of the relations between surface water and aquifers, as well as the diversity of points of view and interests (private and public), only very rarely make it possible to reach a consensus that will make it possible to reconcile economic development, land use planning, sustainable management of water resources and protection of the natural environment.

Integrated management is today an essential approach to sustainable water resource management. However, if the concept seems relevant, its concrete application at the local level has yet to be undertaken, with all the difficulties related to the complexity implied by the issue.

In Morocco, water management as it is practiced today, does not meet a growing demand and does not allow the preservation of aquatic environments. However, regulation and technology are essential to arbitrate the uses, increase the availability of resources and reduce pollution and especially, to make the system last in the medium term.

In conclusion, the problem of water resources has become more than ever a problem of governance. Efforts are still needed to promote intra-sectoral convergence and coordination, consultation and intermediation between the various stakeholders involved in water management and to ensure the integration of scientists and representatives of associations in local decision-making and to raise awareness among citizens of a culture of sharing, common good and preservation of water resources.

\section{Acknowledgements}

The authors would like to thank the GISEC project team and the Hassan II Academy of Science and Technology for being the pillars of the success of this project.

This work is dedicated to the late Mohamed Qarro who contributed enormously to its realization. May God have him in his holy mercy.

\section{Conflicts of Interest}

The authors declare no conflicts of interest regarding the publication of this paper. 


\section{References}

[1] Billaud, J.-P., Gana, A., Harff, Y., Honegger, A., Badache, L. and Puech, D. (2006) Crise hydraulique et inégalités face au risque. Recherche préliminaire, in «Coordinations hydrauliques et justices sociales». Actes du séminaire novembre 2004, Montpellier.

[2] El Battiui, M. (2010) La gestion de l'eau au Moyen-Orient. L'Harmattan, Paris, 274 p.

[3] Benzekri, E.M. (2006) 50 ans de politique de l'eau au Maroc. https://fr.scribd.com/document/241156065/50-Ans-de-Politique-de-1-Eau

[4] Lazarev, G. (2012) Les politiques agraires au Maroc. 1956-2006. Un témoignage engagé. Economie Critique, 1, 53-62

[5] Mouhtadi, N. (1999) Essai sur la communication politique au Maroc. Communication, 19, 11-40.

[6] Swearingen (1987) Terre, politique et pouvoir au Maroc. Revue de l'Occident Musulman et de la Méditerranée, No. 45, 41-54. https://doi.org/10.3406/remmm.1987.2169

[7] Benkhattab, A. (2010) Politiques publiques, réformes politiques et résistance au changement au Maroc. Séminaire organisé par l'IRES: Le processus des réformes au Maroc: Quelle cohérence d'ensemble pour quels effets sur la compétitivité globale du pays? Version provisoire.

[8] Sehring, J. (2006) The Politics of Water Institutional Reform A Comparative Analysis of Kyrgyzstan and Tajikistan. 2006 Berlin Conference on Human Dimensions of Global Environmental Change "Resource Policies. Effectiveness, Efficiency and Equity”, Berlin, 17-18 November 2006, 2-12.

[9] El Menouar, A. (2012) Pour une gouvernance optimale de l'eau au Maroc. Edition Imprimerie Bidaoui, Casablanca, $279 \mathrm{p}$.

[10] Tazi Sadeq, H. (2006) Du droit de l'eau au droit à l'eau, au Maroc et ailleurs. Ed. EDDIF, Casablanca, $460 \mathrm{p}$.

[11] El Faiz, M. (2001) La Grande Hydraulique dans le Haouz de Marrakech: Fascination technologique et émergence du pouvoir des ingénieurs. In: Gobe, E., Ed., Les ingénieurs maghrébins dans les systèmes de formation, Systèmes de formation Filières coloniales et pratiques professionnelles Professionnalités contemporaines. Actes de la réunion intermédiaire du programme Ingénieurs et société au Maghreb, Rabat, Maroc, 213-225.

[12] Bouderbala, N. (1999) Les systèmes de propriété foncière au Maghreb. Le cas du Maroc. In: Jouve, A.M. and Bouderbala, N., Eds., Politiques foncières et aménagement des structures agricoles dans les pays méditerranéens: A la mémoire de Pierre Coulomb, CIHEAM, Montpellier, 47-66.

[13] Perennes, J. (1993) L'eau et les hommes au Maghreb: Contribution à une politique de l'eau en Méditerranée. KARTHALA Editions, Paris, 646 p.

[14] Saaf, A. (2015) Changement et continuité dans le système politique marocain. In: Dupret, B., Rhani, Z., Boutaleb, A. and Ferrié, J.-N., Eds., Le Maroc au présent: D’ une époque à lautre, une société en mutation, Centre Jacques-Berque, Casablanca, 535-568.

[15] Arrifi, E.M. (2008) La gestion intégrée en eau au Maroc: ressources, contraintes et implications sur l'économie d'eau. Revue HTE No. 140.

[16] Agoumi, A. and Debbarh, A. (2006) Ressources en eau et bassins versants du Maroc. 50 ans de développement (1955-2005), 28 p. 
[17] Le Tellier, J. (2006) Les recompositions territoriales dans le Maroc du Nord. Dynamiques urbaines dans la péninsule tingitane et gouvernance des services de base à Tanger et à Tétouan (Maroc) L'inclusion des quartiers pauvres à travers l'accès aux transports et à l'eau potable. Geography. Université de Provence-Aix-Marseille I, Marseille.

[18] Molle, F. and Hoanh, C.T. (2009) Implementing integrated river basin management: Lessons from the Red River Basin, Vietnam. International Water Management Institute, Colombo, $33 \mathrm{p}$.

[19] Cole, A. and Eymeri-Douzans, J.M. (2010) Introduction: Les réformes et les regroupements administratifs en Europe-Questions de recherche et défis empiriques. Revue Internationale des Sciences Administratives, 76, 423-434. https://doi.org/10.3917/risa.763.0423

[20] Huerta Melchor, O. (2008) La gestion du changement dans l'administration des pays de l'OCDE: Un premier aperçu général. Documents de travail sur la gouvernance publique. No.12, éditions OCDE, Paris. https://doi.org/10.1787/227138426766

[21] Eymeri-Douzans, J.M. (2008) Les réorganisations administratives. Publication de l'IGPDE/Recherche-Etudes-Veille. No. 27.

[22] Blomquist, W., Dinar, A. and Kemper, K. (2005) Comparison of Institutional Arrangements for River Basin Management in Eight Basins. Policy Research Working Paper No. 36, World Bank, Washington DC. https://doi.org/10.1596/1813-9450-3636

[23] Mitchell, B. (1990) Integreted Water Management. In: Mitchll, B., Ed., Integreted Water Management. International Experiences and Perspectives, Belhaven Press, London, 1-21.

[24] Ghiotti, S. and Haghe, J.P. (2004) Bassin versant et politique de décentralisation: Une instrumentalisation. Cybergeo Presse, Paris.

[25] Affeltranger, B. and Lasserre, F. (2003) La gestion par bassin versant: Du principe écologique à la contrainte politique. Vertigo, 4, 5.

[26] Clarimont, S. (2009) L'évolution des politiques française et espagnole de l'eau. Entre directives communautaires et décentralisation administrative. Economie Rurale, 309, 34-49.

[27] Lanfranchi, G. (2008) Gouvernance de l'eau à l'échelle du bassin versant français: Etat des lieux et dispositifs d'évaluation. Synthèse technique. AgroParisTech-ENGREF à Montpellier et Office International de l'Eau.

[28] Ténière-Buchot, P.F. (2013) Viewpoint-Happy Like a Clam in French Water. Water Alternatives, 6, 218-238.

[29] Guerrin, J. and Bouleau, G. (2014) Remparts ou menaces ? Trajectoires politiques de l'endiguement en France, aux Pays-Bas et aux États-Unis. Revue Internationale de Politique Comparée, 21, 89-109. https://doi.org/10.3917/ripc.211.0089

[30] Huitema, D. and Meijerink, S. (2017) The Politics of River Basin Organizations: Institutional Design Choices, Coalitions, and Consequences. Ecology and Society, 22, 42. https://doi.org/10.5751/ES-09409-220242

[31] Allal, A. (2007) «Développement international » et " promotion de la démocratie»: A propos de la «gouvernance locale» au Maroc. L'Année du Maghreb.

[32] Wagle, S., Warghade, S., Pol, T. and Sathe, M. (2015) Water Security: Assessing the Role of Reforms Related to Independent Regulatory Authorities in India. In: Gurtoo, A. and Williams, C., Eds., Developing Country Perspectives on Public Service 
Delivery, Springer, New Delhi, 117-134.

https://doi.org/10.1007/978-81-322-2160-9 8

[33] Mukhtarov, F. and Daniell, K.A. (2017) Transfer, Diffusion, Adaptation, and Translation of Water Policy Models. The Oxford Handbook of Water Politics and Policy. Oxford University Press, Oxford.

https://doi.org/10.1093/oxfordhb/9780199335084.013.30

[34] Barraqué, B. and Laigneau, P. (2017) Agences de l'eau: Rétrospection prospective. Annales des Mines-Responsabilité et environnement, 87, 114-120. https://doi.org/10.3917/re1.087.0114

[35] Buchs, A. (2012) Observer, caractériser et comprendre la pénurie en eau. Une approche institutionnaliste de l'évolution du mode d'usage de l'eau en Espagne et au Maroc. Thèse de doctorat, Université de Grenoble, Grenoble. 